\title{
Prizes fail to quell disquiet over UK policy
}

London. Britain's Department of Trade and Industry (DTI) announced last week that it is to offer six annual prizes, with a total value of $£ 150,000$, to reward projects aimed at encouraging technology transfer and linking universities to industry.

It also, somewhat more obscurely, announced what it described as "a new blueprint for science engineering and technology policy in Britain" under the title Extend Quality Life - or EQuAL (sic) - which it defined as a way of integrating "the entire spectrum of scientific, technological economic and social activities".

Both initiatives, which took many UK research administrators by surprise, were launched at a press conference organized in response to widespread concern about the government's controversial decision to transfer the Office of Science and Technology from the Cabinet Office to the DTI (see Nature 376, 103 and 206; 1995).

Government officials continue to defend the move. At the press conference, Ian Taylor, the new junior minister for science and technology, justified it on the grounds that while Britain remained strong in curiosity-driven research, "the transfer of ideas to industry is very patchy". Moving the OST to the DTI - and thus closer to industry was therefore a "logical step" that puts the

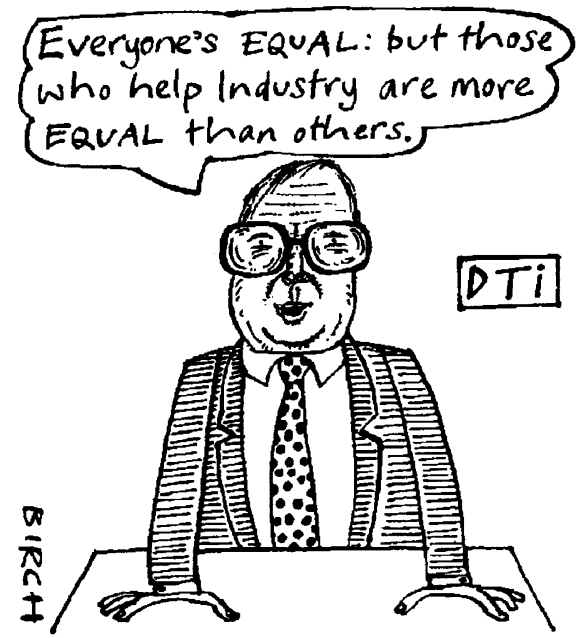

activities of the research councils for whom OST is responsible "on a bigger platform".

Taylor also defended the fact that, as a result of the move, the chief scientific adviser (CSA) to the government, a post to be taken up at the beginning of September by Robert May of the University of Oxford, will now operate from the DTI. "To detach the CSA from the rest of OST would be great mistake," he said.

There was further support from Sir William Stewart, the government's chief scientific adviser from 1990 until last month. In a newspaper article, Stewart wrote that the shift to the DTI was a "shrewd move" that could lead to "one of the strongest infrastructural groupings in the world".

But, even if the initial outcry has died down, many scientists remain convinced that pressures will increase on the science base to meet the short-term needs of industry, and that politically, science has been demoted. "The move seems to show that the government feels scientists should be on tap, and not on top," said one observer.

As further evidence of this, in a reshuffle of cabinet committees, the science subcommittee was last week disbanded, and its functions merged into a new ministerial committee on economic and domestic policy and competitiveness. The committee will be chaired by Michael Heseltine, former head of the DTI and a strong believer in harnessing science firmly to the needs of British industry, who is now deputy prime minister.

Cabinet responsibility for science now rests with Ian Lang, the new president of the Board of Trade. According to Taylor, Lang will "make sure that the science voice will be heard at the government level". But there are reports - which DTI officials deny that Lang was a less than fully active participant in a meeting last week of the government's Council for Science and Technology, which he now chairs. He was also reported, in an interview with the Daily Telegraph, to have told Taylor to take over as minister for science and technology "to keep the scientific community happy".

Whether the reports are true or not, last Friday's press conference seemed to be more of a damage limitation exercise than an attempt to set out any carefully crafted new policy initiatives. Its defensive tone was evident in a statement issued by Taylor, arguing that the government "has in no way downgraded science and engineering".

The statement also emphasized that "quality of life [is] not a poor relation" — an apparent reference to the concern generat- ed by the initial announcement of the shift of the OST to DTI which described the mission of the science base merely in terms of its potential contribution to national "wealth creation".

EQuAL, said Taylor, is a reflection of this new commitment. He said that it required the integration of activities ranging from "fundamental molecular science (genetics, physics, chemistry) to long-range diagnostics and new patterns of work and leisure". And Taylor added that some of the funds being awarded to support the pursuit of strategic goals outlined in the recent Technology Foresight exercise would be directed towards EQuAL's components.

But lacking any clear mandate, specified goals or organizational details on how EQuAL will be administered - or even any commitments to new funding - many were left wondering whether the "new initiative", which appears to have had little detailed discussion in science advisory circles, will prove much more than an attempt to paper over the cracks in the government's reputation.

Certainly the Royal Society remains lukewarm. While refraining from overt criticism of the government's moves, the society's council issued a statement last week saying that it was keen to hear further details of the thinking behind the restructuring.

There is a growing feeling that some of this nervousness will disappear if the government is able to secure the continued existence of the House of Commons Select Committee on Science and Technology, now threatened with being subsumed into the committee that covers the whole of trade and industry. The Royal Society is one among many groups that have expressed a desire to see the select committee's survival. A decision is expected in October when parliament meets for the beginning of its new session.

David Dickson

\section{Equality in sight for contract research staff}

London. Contract research staff at British universities will be employed on terms equivalent to their full-time peers, according to a draft 'concordat' released last week by the Committee of Vice Chancellors and Principals (CVCP).

The document proposes equal pay, pensions and leave for fixed-term contract researchers, whose numbers have risen fourfold to 18,000 over the past 12 years. It also agrees to recognize previous experience when arranging salaries and career development.

"It is essential that universities can recruit from the best researchers," says Kenneth Edwards, chairman of the CVCP. But the concordat advises contract staff not to view a fixed-term research post as the first step to fulltime academic employment. "This is realistic only for a minority," it says.

The Association of University Teachers (AUT) welcomed the concordat as a belated step in the right direction. But the AUT's national president, Peter Breeze, pointed out that it failed to recommend an end to waiver clauses on unfair dismissal and redundancy.

The consultative document, which stems from the 1993 science White Paper, was drafted by a group led by the Office of Science and Technology, with input from the research councils, the Royal Society and the CVCP. A final version is expected to be approved by the end of the year.
Ehsan Masood 